Procedia of Engineering and Life Science Vol. 1. No. 2 Juni 2021

Seminar Nasional \& Call Paper Fakultas Sains dan Teknologi (SENASAINS 2nd) Universitas Muhammadiyah Sidoarjo

\title{
Video Conference Application with File Attachment
}

\section{Aplikasi Video Conference dengan File Attachment}

\author{
Dini Yocta Prabayanti ${ }^{1}$, Ade Eviyanti ${ }^{2}$ \\ \{yoctadini@gmail.com¹ ${ }^{1}$, adeeviyanti@umsida.ac.id ${ }^{2}$ \} \\ Universitas Muhammadiyah Sidoarjo,Indonesia ${ }^{1}$
}

\begin{abstract}
Communication today is a human need as a social creature. In accordance with technological advances, communication can be in the form of instant messages such as WhatsApp, telegram and video conference, video conference services can communicate face-to-face with other users. Video conference in the most popular appstore and playstore, namely zoom meetings. Zoom meting makes it easy for users to create and schedule online meetings. the application is not equipped with file sharing services. In this case, users find it difficult to send files to other users who join the online meeting. The video conference application with a file attachment makes it easy in the morning for online meeting users to create, schedule and share files into online meetings. It is hoped that with this application users can easily share files in online meetings. This system is made with a simple interface design that is easy to understand for using the application. The purpose of this research is to make it easier for people to conduct online meetings. The method used is the waterfall method, while the data collection technique is quantitative data technique. The desired result of the research is to make it easier for people to conduct online meetings and send data through this application without having to open another application.
\end{abstract}

Keywords - Distance education system; online meeting; video conference

\begin{abstract}
Abstrak. Komunikasi saat ini merupakan kebutuhan manusia sebagai makhluk sosisal. Sesuai dengan kemajuan teknologi, komunikasi dapat berupa pesan instan seperti whatsapp, telegramm dan video conference, layanan video conference dapat melakukan komunikasi dengan bertatap muka dengan pengguna lain. Video conference pada appstore dan playstore paling popler yaitu zoom meeting. Zoom meting memudahkan pengguna dalam membuat dan menjadwalkan meeting online. aplikasi tersebut belum dilengkapi dengan layanan berbagi file. Dalam hal itu membuat pengguna merasakan kesulitan untuk melakukan pengiriman file ke pengguna lain yang bergabung pada meeting online. Aplikasi video conference dengan file attachment memberikan kemudahan pagi pengguna meeting online dalam membuat, menjadwalkan dan berbagi file kedalam meeting online. Diharapkan dengan adanya aplikasi ini pengguna dapat dengan mudah berbagi file dalam meeting online. Sistem ini dibuat dengan rancangan antar muka yang sederhana yang mudah dipahami untuk menggunakan aplikasi. Tujuan penelitian ini adalah untuk mempermudah orang melakukan meeting online. Metode yang di gunakan ialah metode waterfal,sedangkan Teknik pengumpulannya datanya adalah Teknik data kuantitatif. Hasil yang diinginkan dari penelitian adalah mempermudah orang melalukan meeting online dan mengirim data melalului aplikasi terserbut tanpa harus membuka aplikasi lainnya .
\end{abstract}

Kata Kunci - sistem pendidikan jarak jauh; online meeting; video conference

\section{Pendahuluan}

Berdasarkan data appstore dan playstore aplikasi video converance yang paling populer saat ini adalah Zoom Meeting. Aplikasi zoom meeting disukai oleh pengguna, karena kemudahan untuk membuat atau menjadwalkan pertemuan (meeting) online. Begitu juga untuk mengundang teman agar ikut bergabung pada meeting online dapat dilakukan dengan cara cukup membagikan (share) link [1]. Adapun aplikasi Video conference milik google, antara lain adalah Google meet banyak digunakan oleh user ditengah pandemi Virus Corona atau Covid-19. Berdasarkan data dari firma, Riset Applikasi yang bernama Brains,applikasi ini adalah applikasi Pesaing dari Applikasi Zoom Meet tersebut sudah diunduh atau di download sebanyak 50.000.000 (Lima Puluh Juta) kali di google playstore [2].

Peningkatan jumlah unduhan ini didorong oleh pengguna (user) yang berbondong-bondong mengunduh meet pasca digratiskan pada platform tersebut belum lama ini,sebelumnya pengguna yang ingin membuat ruangan rapat virtual di platform Video Conference meet memang harus membayar untuk berlangganan G-suite [3]. Meskipun begitu angka tersebut belum mampu menandingi jumlah unduhan aplikasi zoom meeting di toko aplikasi yang sama.

Pantauan KompasTekno di aplikasi google playstore, yang terbit pada hari selasa tanggal 09/05/2020 [4]. Zoom Meeting telah diunduh dua kali lipat dibandingkan dengan meet,dengan unduhan lebih dari 100.000 .000 user (pengguna), meskipun demikian tidak menutup kemungkinan jika angka unduhan aplikasi meet terus mengalami peningkatan seiring dengan berjalannya waktu, dan bisa jadi melampaui jumlah user dari applikasi zoom, apalagi platform video conference dilengkapi dengan berbagai fitur yg di klaim lebih aman dibandingkan aplikasi zoom [5]. 
Kedepannya, Google juga berencana untuk menambahkan sejumlah fitur terbaru di applikasi meet, seperti diantaranya adalah mode low-light untuk meningkatkan kualitas video di suasana minim pencahayaan, dan fitur noise cancellation yang terintegrasi yang berfungsi untuk meredam suara di sekitar pengguna (user) [6].

Adapun kelebihan dari applikasi google meet adalah tampilan video lebih jernih dengan kualitas HD ketika melakukan video converense, di applikasi google meet dilengkapi dengan layanan enkripsi video, dan kekurangan dari google meet sendiri antara lain yang pertama adalah belum adanya fitur hemat data,karena dengan adanya fitur hemat data tentunya akan membuat penggunaan data tidak boros, yang kedua adalah ketika user menggunaan video conference diharuskan memiliki kesetabilan jaringan internet yang memadai [7].

Berdasarkan latar belakang diatas dapat disimpulkan para orang tua membutuhkan aplikasi. Oleh karena itu penulis membantu dengan mengembangkan aplikasi berbasis web yang bertujuan untuk memudahkan para pengguna. Dari penelitian ini penulis mengangkat judul “Aplikasi Video Conference Dengan File Attachment”.

\section{METODE}

Penelitian ini dilaksanakan di Kota Sidoarjo dan dilaksanakan dengan rentang waktu 3 (tiga) bulan, yakni pada bulan September - November tahun 2020. Pada tahapan Metode perancangan ini yang digunakan peneliti adalah metode waterfall untuk mengembangkan perangkat lunak secara berurutan. Dimana kemajuan dipandang sebagai terus mengalir ke bawah seperti air terjun yang melewati fase-fase analisa, perancangan, penerapan, pengujian sistem, dan perbaikan [8]. Maka peneliti menggunakan metode waterfall sebagai penunjang keberhasilan dalam pembuatan suatu program yang akan dibuat.

Analisa program ini merupakan pengumpulan survey berupa wawancara dan penyebaran kuisioner dengan target beberapa orang. Menghasilkan kesimpulan bahwa aplikasi zoom versi mobile memiliki kekurangan yaitu tidak dapat melakukan pengiriman file. Perancangan aplikasi dilakukan setelah melakukan studi bedah aplikasi zoom mobile dan membandingkan dengan aplikasi mobile conference lain seperti Google Meets dan Cisco WebEX. Kemudian disimpulkan bahwa aplikasi mobile conference lain juga memiliki kekurangan yang sama [9].

Tahap pengumpulan data dan analisis yaitu tahap yang dilakukan peneliti dalam melakukan pengumpulan data dan juga menganalisis permasalahan yang ada. Pada penelitian ini penulis melakukan beberapa tahapan untuk dalam melakukan pengumpulan data maupun menganalisis masalah antara lain : studi literatur, pengumpulan data, analisis perancangan metode.

Penulis melakukan pengumpulan data untuk dijadikan sebagai acuan atau literatur pada penelitian ini dari penelitian sebelumnya yang sejenis dengan penelitian yang akan dilakukan. Tahapan kedua yang dilakukan setelah melakukan tahapan studi literatur. Pada tahapan ini pengumpulan data dilakukan dengan cara wawancara. Tahapan yang dilakukan untuk meracang sistem tersebut adalah menggunakan metode model SDLC (System Development Life Cycle) yang merupakan pola untuk mengambil pengembanan sistem perangkat lunak, yang terdiri dari tahap-tahap: rencana (planing), analisa (analysis, desain (design), implementasi (implemaentation), uji coba (testing), dan pemeliharaan (maintenance) [10].

Berdasarkan hasil observasi dan wawancara, aplikasi zoom meeting memiliki kekurangan fitur untuk berbagi file atau file attachment. Hal ini membuat pengguna aplikasi Zoom Meeting tidak dapat mengirim data kepada lawan conveference seperti mengirimkan data melalui aplikasi email atau whatsapp.

Tahap yang diakukan oleh penulis ialah pemrograman, pada tahap ini merupakan hasil implementasi perancangan kedalam bahasa pemrograman guna mejudkan suatu sistem yang diharapkan selanjutnya penguian jika lolos uji maka sistem akan diinstal dan di operasikan.

Tahap berikutnya dilakukan pengujian sistem dimana pengujian dilakukan disetiap masing-masing fitur guna mengetahui apakah fitur bekerja sesuai dengan yang diharapkan atau sebaliknya. Pengujian ini penulis menggunakan metode blackbox testing, uji coba ini digunakan untuk mendemonstrasikan fungsi software.

Adapun yang dilakukan penulis dalam perancangan sistem aplikasi ini yaitu rancangan flowchart sistem, rancangan use case diagram aplikasi, rangkuman use casee, dan rancangan antar muka (User Interface).

\section{Hasil dan Pembahasan}

\section{A. Hasil}

Berdasarkan hasil perancangan sistem yang telah dibuat dari pembahasan sebelumnya, penulis dapat menerapkan ke dalam bentuk pembuatan aplikasi yang berjudul “Aplikasi Video Conference Dengan File Attachment”. Berikut ini merupakan tampilan antar muka dari aplikasi yang telah dibuat dari perancangan aplikasi tersebut.

Tabel 1. Hasil Pengujian integration testing

$\begin{array}{cccc}\text { Pengujian } & \begin{array}{c}\text { Tujuan } \\ \text { pengujian }\end{array} & \begin{array}{c}\text { Hasil yang } \\ \text { diharpkan }\end{array} & \text { Kesimpulan }\end{array}$


Procedia of Engineering and Life Science Vol. 1. No. 2 Juni 2021

Seminar Nasional \& Call Paper Fakultas Sains dan Teknologi (SENASAINS 2nd) Universitas Muhammadiyah Sidoarjo

\begin{tabular}{|c|c|c|c|}
\hline $\begin{array}{l}\text { Membuka } \\
\text { aplikasi }\end{array}$ & $\begin{array}{l}\text { Mengetahui apakah } \\
\text { aplikasi berjalan } \\
\text { sesuai dengan yang } \\
\text { di inginkan tanpa } \\
\text { terjadi error atau } \\
\text { tidak }\end{array}$ & $\begin{array}{l}\text { Aplikasi berjalan } \\
\text { dengan baik dan } \\
\text { menampilkan } \\
\text { halaman login }\end{array}$ & Berhasil \\
\hline $\begin{array}{c}\text { Melakukan } \\
\text { login }\end{array}$ & $\begin{array}{c}\text { Mengetahui apakah } \\
\text { login dapat } \\
\text { dilakukan }\end{array}$ & $\begin{array}{l}\text { Aplikasi berjalan } \\
\text { dengan baik dan } \\
\text { menampilkan } \\
\text { halaman beranda }\end{array}$ & Berhasil \\
\hline $\begin{array}{l}\text { Memilih menu } \\
\text { pada beranda }\end{array}$ & $\begin{array}{l}\text { User dapat } \\
\text { memilih menu } \\
\text { yang ada pada } \\
\text { aplikasi }\end{array}$ & $\begin{array}{l}\text { Aplikasi berjalan } \\
\text { dengan baik dan } \\
\text { menampilkan } \\
\text { halaman menu } \\
\text { yang dipilih user }\end{array}$ & Berhasil \\
\hline $\begin{array}{c}\text { Menambahkan } \\
\text { add schedule, } \\
\text { new meeting, } \\
\text { join meeting pada } \\
\text { aplikasi }\end{array}$ & $\begin{array}{c}\text { User dapat } \\
\text { menambahkan } \\
\text { schedule, meeting } \\
\text { baru, dan join } \\
\text { meeting } \\
\text { yang sudah ada }\end{array}$ & $\begin{array}{l}\text { menyimpan data } \\
\text { yang di lakukan user } \\
\text { melalui aplikasi }\end{array}$ & Berhasil \\
\hline $\begin{array}{l}\text { Keluar } \\
\text { aplikasi }\end{array}$ & $\begin{array}{c}\text { user dapat keluar } \\
\text { aplikasi }\end{array}$ & $\begin{array}{c}\text { Aplikasi keluar } \\
\text { dengan baik tanpa } \\
\text { adanya } \\
\text { kesalahan }\end{array}$ & Berhasil \\
\hline
\end{tabular}

Tabel 2. Hasil wawancara

\begin{tabular}{|c|c|c|c|c|c|c|c|}
\hline No. & Pertanyaan & SSx 5 & $\mathrm{Sx} 4$ & $\mathrm{RRx3}$ & TSx2 & STSx1 & Jumlah \\
\hline 1 & $\begin{array}{l}\text { Apakah login } \\
\text { mudah dilakukan? }\end{array}$ & 10 & 8 & 3 & 0 & 0 & 21 \\
\hline 2 & $\begin{array}{l}\text { Apakah mudah } \\
\text { untuk membuat } \\
\text { meeting? }\end{array}$ & 10 & 0 & 9 & 0 & 0 & 19 \\
\hline 3 & $\begin{array}{l}\text { Apakah mudah } \\
\text { join meeting } \\
\text { dengan user lain? }\end{array}$ & 15 & 8 & 0 & 0 & 0 & 23 \\
\hline 4 & $\begin{array}{l}\text { Apakah aplikasi } \\
\text { mudah di } \\
\text { gunakan? }\end{array}$ & 10 & 8 & 3 & 0 & 0 & 21 \\
\hline 5 & $\begin{array}{l}\text { Apakah informasi } \\
\text { dalam aplikasi sesuai } \\
\text { dengan } \\
\text { kebutuhan? }\end{array}$ & 5 & 8 & 6 & 0 & 0 & 19 \\
\hline
\end{tabular}

\section{B. Pembahasan}

Pada pembahasan ini penulis akan menguraikan tentang proses danfungsi rancangan sistem aplikasi yang telah dibuat dari perancangan sebelumnya.

Pada halaman login aplikasi terdapat texview yang berisikan nama apliaksi, logo aplikasi, inputan email dan password, tombol login. User jika ingin menggunakan aplikasi ini harus memiliki akun zoom yang digunakan untuk login keaplikasi menggunakan email dan password yang sudah didaftarkan pada akun zoom.

Pada halaman beranda terdapat pilihan menu new meeting, join, schedule, logout, riwayat meeting dan nama user. Di halaman ini user akan memilih yang dibutuhkan, jika user ingin membuat meeting baru user memilih new meeting, jika user ingin ikut/masuk kedalam meeting yang sudah ada user akan memilih menu join, jika user ingin melihat schedule yang sudah ada user memilih menu schedule, jika user ingin keluar dari akun user menekan tombol logout.

Pada halaman new meeting terdapat menu audio, video, upload file, partisipasi, more, tombol leave, id, password user, dan tampilan video. Pada halaman ini terdapat id dan password user yang digunakan untuk user lain yang ingin masuk ke dalam meeting user tersebut. Pada halaman ini berfungsi jika user menekan tombol upload file yang ada pada halaman new meeting. Setelah user menekan tombol upload akan muncul tombol file dan tombol upload. 
Procedia of Engineering and Life Science Vol. 1. No. 2 Juni 2021

Seminar Nasional \& Call Paper Fakultas Sains dan Teknologi (SENASAINS 2nd)

Universitas Muhammadiyah Sidoarjo

Pada halaman ini terdapat tampilan list participants, tombol invite, mute, dan close. Setiap tampilan tersebut memiliki fungsi yang berbeda. List participant akan menampilkan seluruh user yang mengikuti meeting. Tombol invite berguna mengajak user lain untuk join meeting dengan mengundangnya melalui pesan, gmail, email, dan copy invite link. Sedangkan tombol mute untuk menonaktifkan suara user yang mengikuti meeting.

Pada halaman join meeting terdapat tampilan input id dan tombol join. Pada tampilan ini jika user ingin masuk kedalam meeting harus menginputkan id dari meeting yang sudah ada, kemudian tekan tombol join untuk masuk kedalam meeting online. Setelah user sudah menginputkan id meeting yang sudah ada user akan masuk kelayout meeting.

Pada halaman schedule meeting terdapat tampilan list history meeting dan tombol add schedule yang digunakan untuk menambahkan schedule meeting baru. Di dalam list history meeting terdapat tampilan yang menunjukkan time, host, topic, meeting number, dan meeting password tampilan tersebut. Pada tahap pengujian sistem dilakukan pengujian untuk mengetahui aplikasi sudah berjalan sesuai dengan rancangan sistem dan apakah masih ada kesalahan saat aplikasi digunakan.

Pengujian user interface

Didapatkan pengujian user interface dari apliakasi dari setiap layout sesuai dengan yang diinginkan tanpa adanya kesalaham atau error.sesuai dengan yang diinginkan.

Pengujian integration testing

Pada pengujian ini aplikasi akan diuji menggunakan metode blackbox agar mengetahui apakah aspek fungsi pada aplikasi berhasil dan sesuai dengan yang di inginkan. Berdasarkan tabel diatas dapat disimpulkan bahwa pengujian yang dilakukan pada aplikasi sesuai dengan yang di inginkan dan dapat dikatakan berhasil dari setiap pengujian.

\section{Hasil pengujian user}

Aplikasi ini telah dibuat dan telah di ujikan kepada 5 responden sistem berjalan dengan baik dan sesuai dengan yang di inginkan. Berdasarkan hasil dari presentase setiap pertanyaan dari pengujian 5 user dapat disimpulkan bahwa aplikasi yang telah dibuat sangat mudah menggunakan aplikasi dan informasi yang ada pada aplikasi sesuai dengan kebutuhan user.

\section{KESIMPULAN}

Berdasarkan dari hasil pengujian dan analisa yang telah dilakukan pada aplikasi video conference dengan file attachment maka dapat disumpulkan bahwa aplikasi dapat digunakan sebagai pertemuan online atau meeting online dan dapat mengirimkan file yang dapat membantu pertemuan dan aplikasi memliki tampilan antar muka yang sederhana sehingga sangat mudah untuk digunakan.

\section{UCAPAN TERIMA KASIH}

Penulisan artikel ilmiah yang berjudul Aplikasi Video Conference dengan File Attacment ini melibatkan berbagai pihak, baik secara langsung maupun secara tidak langsung. Oleh karena itu, pada kesempatan ini penulis menyampaikan ucapan terima kasih kepada semua pohak yang terkait.

\section{REFERENSI}

[1] Gajalakshmi. (2016). SOFTWARE DEVELOPMENT LIFECYCLE MODEL (SDLC) INCORPORATED WITH RELEASE MANAGEMENT. International Research Journal of Engineering and Technology (IRJET).

[2] Herryawan, K. (2016). Video Conference. Pusat Teknologi Informasi dan Komunikasi Pendidikan Departemen Pendidikan Nasional.

[3] Abdullah. (2015). Web Programming is Easy. Jakarta: PT Elex Media Komputindo.

[4] Rodríguez Martínez, L. (2012). Review of Relevant System Development Life Cycles (SDLCs) in ServiceOriented Software Engineering (SoSE). Journal of Applied Research and Technology, 94-113.

[5] Amsyah, Z. (2018). Manajemen Sistem Informasi. Jakarta : Gramedia.

[6] Ladjamudin., A.-B. B. (2016). Analisis dan Desain Sistem Informasi. Yogyakarta: Graha Ilmu.

[7] Mining, W. I. (2016). Data Mining: Concepts and Techniques. Morgan Kaufinann.

[8] Raharjo, B. (2015). Belajar Otodidak Framework CodeIgniter. Bandung: Informatika.

[9] Nugroho, E. (2018). Sistem informasi manajemen: Konsep, aplikasi, dan perkembangannya.Yogyakarta: Andi.

[10] Nurdiansyah, D. C. (2015). IMPLEMENTASI VIDEO CONFERENCE PADA JARINGAN HSUPA (HIGH SPEED UPLINK PACKET ACCESS) DENGAN MEDIA IPv6 MENGGUNAKAN SIMULATOR OPNET MODELER v.14.5. Jurnal Skripsi. 